\title{
Ousados e insubordinados: protesto e fugas de escravos na província do Grão-Pará - 1840/1860
}

\section{José M aia Bezerra Neto}

\section{Haiti não era longe daqui: subversão e fugas de escravos}

$\mathbf{E}^{\mathrm{n} 27}$

m 27 de maio de 1840, M anoel G onçal ves L oureiro, prometendo a gratificação de cem mil-réis, anunciava nas páginas do Treze de $M$ aio que seu escravo Ernesto havia fugido da cidade de Belém há "vinte annos pouco mais ou menos", em torno de 1820. $\mathrm{N}$ a época da fuga, Ernesto ainda moleque, "10 a 12 annos quando fugio", aprendia o ofício de alfaiate. Sobre o período em que vivenciou a liberdade, tornando-se homem feito, nada se sabe, porém, seu senhor "tendo notícia a poucos tempos que anda nos subúrbios desta cidade [Belém] nos districtos do rio Guamá, Jangapi, C apim ePernambuco", não perdia as esperanças detêlo maisuma vez sob seu mando! (Treze de M aio, 27/05/1840, p. 04).

João M endes da Silva, residente na vila da Vigia, em 19 de julho de 1845 também andava às voltas com seu escravo D omingos Antônio, em fuga desde 1829. Seu senhor soube, então, que "este escravo existe no districto deÓ bidos [Baixo Amazonas], dizendo-se, valha a verdade, ser visto em casa de M arcos D olosan", solicitando providências às "authoridades territoriais, e policiaes dos districtos de Ó bidos acerca do possível couto do escravo fugitivo", bem como prometia $100 \$ 000$ rs. a "quem offerecer provas legaes contra 0 acoutador, para haver delle percas, damnos causados, e dias de serviço". N a verdade, João M endes da Silva, como outros tantos senhores, ficava às turras com o fato de que D omingos Antônio, como "outros escravos fugidos, tem esperança vital nos seus acoitadores" (Treze de M aio, 19/07/1845, p. 04).

As histórias citadas acima não são casos únicos. D urante toda a primeira metade do século XIX, no bojo das agitações políticas próprias ao 
processo de independência e formação do império brasileiro, as fugas de escravos não só aconteciam em grande número, como adquiriam novos significados políticos com a associação feita pelos escravos entre a ruptura política da colônia em relação ao domínio português com a própria abolição da escravatura. ${ }^{1} \mathrm{~N}$ o início da década de 1820 , segundo Palma M uniz, os escravos "com suas pretensões de liberdade, salientaram-senasfugas dos senhores e internação pelo interior, havendo sido, nesse período, um dos empregos da força militar de linha a caça desses infel izes nas batidas constantes da ilha do M osqueiro, districto de Barcarena, ilha de 0 nças, rios G uamá e C apim etc. à procura dos mocambos para destruí-los e prender os negros que os constituíam" (1922:140). A própria duração das fugas de Ernesto eD omingos Antônio por longos anos, favorecida por esteperíodo de conturbadas agitações políticas, torna provável que estes fugitivos, entre outros tantos cativos, tenham buscado asilo nos mocambos existentes ou recém-constituídos na província paraense. Também lembre-se que, na mesma época em que Ernesto fugia da cidade de Belém, o G eneral José $M$ aria de $M$ oura, autoridade militar da metrópole portuguesa na Amazônia, dizia que: "D e há muito que nesta cidade se observa que os negros se apresentam em público, e no particular para com seus senhores, com um certo ar altivo, efalando em carta de al forria que, consta, diziam Ihes estava chegando" (M U N IZ, 1922:140). Portanto, os cativos não foram meros espectadores do processo de independência, pelo contrário, associando a sualuta pela liberdadeaosembates contra o domínio colonial lusitano, logo percebiam que se fazia necessário não perder tempo esperando pela abolição, tornando-se necessário obtê-la por conta própria. ${ }^{2}$

Por outro lado, a significativa presença dos escravos entre a população da capital paraense em 1822, representando $46 \%$ da sua totalidade, ou seja, 5.719 pessoas, enquanto os libertos somavam 1.109 e os brancos 5.643 (SALLES, 1988:68-71; 78), fazia com que os temores causados pela ousadia dos escravos preocupassem ainda mais as autoridades e as classes proprietárias. Sendo Belém o principal centro comercial e administrativo da Amazônia, localizada em posição militar privilegiada de controle da entrada e saída do vale amazônico, fazia com que qualquer possibilidade de revolta escrava na capital paraense viesse a ser um perigo temido pelos 
senhores, em épocas tão conturbadas. Entretanto, fazendo-se o império, não se fez a emancipação escrava. O s trabalhadores cativos, então, continuariam buscando os caminhos de sua liberdade nas décadas seguintes, muitas vezes tomando parte nas disputas político-partidárias, pactuando com este ou aqueles setores da população livre em luta aberta contra seus inimigos (RAIO L: 1970:442-443; SALLES, 1988: 266), quando não se limitavam em aproveitar as oportunidades geradas pelas confusões da época para evadir-se, tal como fizera D omingos Antônio em 1829, fugido da vila da V igia. N este sentido, Vicente Salles comparando "a queda quantitativa epercentual da população escrava" do município de Belém, entreos anos de 1822 e 1848, fazendo com que os cativos constituíssem "um terço da população urbana" na última data, diz que a referida diminuição "Significa evasão da mão-de-obra para os mocambos, após os sucessos da Cabanagem [1835]", uma vez que "a partir da C abanagem, a fuga para os mocambos e para os países limítrofes atingiu proporções incalculáveis" (1988: 72-74).

Em 1832, por exemplo, publicava-se no jornal 0 Publicador Amazonense o seguinte documento expedido pelo Juízo Policial de Paz da C ampina, freguesia de Belém:

As imediações da cidade, e todo o interior se acham infestados dum grande número de escravos fugidos, que sempre houveram, mas agora parece quesetem aumentado. Lembra-nosque será conveniente ordenar aosjuízes de paz para que arranjem, como em companhias por del egações, os índiose caboclos, outrora ligeiros, comandados pelos mais hábeis, e ativos, para à ordem dos delegados examinarem o distrito, concedendo-se-Ihes armas, pólvora e terçados, sendo a despeza feita por conta da nação, que tem a obrigação de garantir o sossego, e a tranqüilidade dos povos, ainda que ao depois ela seja indenizada pelos senhores de escravos apreendidos. É necessário prender, e perseguir os escravos fugidos, que ameaçam a segurança pública, e particular, e não descobrimos outro meio, porque as escoltas pelo interior são funestas pelas vexações, e violências, que causam aos povos, e os juízes de paz, e seus delegados são os competentes para estas diligências, conforme a lei de sua criação, que não a põem em prática, ou porque ainda estão no antigo costume de não proceder às diligências, sem ordem expressa da primeira autoridade, ou porque Ihes faltam os meios, as 
armas, e a munição, porque não hão de arrostar um perigo tão grande, sm defesa (Apud Salles, 1988: 211-212 [grifos meus]).

$\mathrm{N}$ a década de 1830, por sinal, a rebeldia escrava acentuou-se durante a C abanagem (1835/1840), ${ }^{3}$ na qual diversas lideranças negras encabeçavam batalhões de escravos fugidos ou aquilombados nas lutas contra as tropas da legalidade, enviadas pel o governo da Regência. N a região do Acará, o preto Félix "à testa de quase quatrocentos escravos"; na zona bragantina, "o preto cristovão, escravo do engenho C araparu", à frente de centenas de escravos e negros livres; na ilha do M arajó, os quilombolas chefiados pelo cafuz C ocô; no Baixo Amazonas, o preto Belisário que comandava "uma força de 300 rebeldes, em maioria negros", são al guns exemplos da participação dos escravose libertos no movimento cabano (SALLES, 1988: 267268). N as palavras de Salles: "N os anos da revolução, ocorreram memoráveis levantes de escravos no Acará, talvez a mais próspera região agrícola e onde havia grande escravatura, e no G uamá, onde se localizava a fazenda Pernambuco, de propriedade do convento do C armo. A revolta dos escravos dessa fazenda constitui um dos episódios mais sangrentos da C abanagem" (1988: 267-268).

É importante lembrar que os escravos elibertos tomando partido da rebel dia cabana não estavam necessariamentesendo levadosà reboque pelos seus senhores e outros segmentos livres, líderes e partidários da revolução. Assim foi que o Preto Félix e $M$ anoel $M$ aria ainda que houvessem seguido Eduardo Angelim, reforçando as suas fileiras, após a prisão do chefe cabano continuaram lutando e combatendo as tropas governamentais. $\mathrm{N}$ a verdade, fazendo política por conta própria, os negros sabiam quea bandeira da abolição não se constituía em ponto comum entre os cabanos, portanto cabia-Ihes lutar pela mesma, enfrentando as represálias por parte de seus partidários de luta contrários a libertação do escravos. Por exemplo, Angel im, terceiro presidente cabano e proprietário do engenho “ $M$ adre de D eus" com dezenas de escravos, mandou fuzilar Joaquim Antônio e Patriota, importanteslíderanças escravas defensoras do abolicionismo. 0 mesmo Angelim quetambém ordenou a seu irmão G eraldo Francisco N ogueira para que debelasse a insurreição dos escravos da região do Acará e outros districtos próximos, contendo os cativos dentro da obediência a seus se- 
nhores. N este sentido, engrossando o caldo da revolução cabana, os negros escravos e libertos, adeptos da liberdade geral e irrestrita para todos, faziam as suas próprias leituras do movimento, procurando imprimir-lhe a sua radicalidade, divergindo dos setores moderados da $\mathrm{C}$ abanagem. Assim foi o caso das reuniões noturnas em queo negro J oão do Espírito Santo, chamado Diamante, organizou um grupo denominado Guerrilheiros, constituindo-se em facção independente e oposta à líderança de Angelim que, tomando ciência, logo dissipara-os (RAIO L, 1970: 934-935). O utros tantos escravos, por sua vez, simplesmente preferiam fazer da ocasião momento propício às suas fugas eà formação de mocambos, abdicando de qualquer participação mais direta nas refregas havidas entre cabanos e legalistas.

D efato, nos jornais paraenses publicados após o término da C abanagem, al guns senhores ainda solicitavam a captura dos seus cativos fugidos na década de 1830. Pedro H onorato Corrêa deM iranda da vila del garapé M iri, distrito de Anapú, por exemplo, em 30 denovembro de 1848 informava que seu escravo $M$ anoel, em fuga desde 1831, estava no Rio de aneiro (0 D outrinário, 30/11/1848, p. 04). Entretanto, nem todos conseguiam ou sequer pretendiam evadir-se para tão longe: Themoteo, também pertencente a Pedro H onorato Corrêa de M iranda, refugiou-se no sertão, eque fugiu em janeiro de 1835, na mesma época em que Belém ficou sob o domínio cabano (0 D outrinário, 30/11/1848, p. 04). Clemente, escravo de José Antônio D 'O liveira Três Irmãos, evadiu-se em 1837, sendo informado ao seu senhor que em 1846 andava pelas ilhas de M acapá e suas vizinhanças, mostrando "falça carta de liberdade" (Treze de M aio, 03/06/ 1846, p. 04).

Com certeza, as medidas de controle social postas em práticas pelo governo provincial, tais como a criação da corporação dos capitães-do-mato, através da lei no 99 de 03 de junho de 1841, visando ao policiamento da Região Amazônica, concomitantemente à derrocada da própria C abanagem, redobravam as esperanças dos senhores em recuperar seus escravos em fuga há bastante tempo. N este contexto, não foi outra a história de M aurício Antônio que, depositado nacadeia pública de Belém em fevereiro de 1845, "como achado do evento", dizia ser escravo "de huma mulher 
deC ametá, moradora nas margens do rio M utuacá, denome Luiza M aria, de quem andava fugido, desde pouco depois que as forças legaes se apoderárão desta capital", ou seja 13 de maio de 1836 (Treze de M aio, 26/ 02/1846, p. 02); igualmente, o africano Simão, natural de M oçambique, escravo dos herdeiros do finado Antônio C outinho da Silva M iranda, foi depositado na cadeia da capital em novembro de 1844, "como achado do evento", após ser preso pelas "forças legaes no rio Acará"; no seu caso, porém, vencido o prazo de sessenta dias, como não houve senhor que o reclamasse legalmente foi vendido em hasta pública em 7 de março de 1845, pelo valor mínimo de sua avaliação em $300 \$ 000$ réis, conforme determinavam as disposições contidas no Regulamento de 9 demaio de 1842 (Treze de $M$ aio, 20/11/1844, p. 03; 26/02/1845, p.02). Assim sendo, fica claro por que os proprietários preocupavam-se em denunciar os fugitivos, solicitando a sua captura, na medida em queas notícias das prisões de escravos fugidos há tempos podiam animá-los a buscar a recaptura daquelesquelhes haviam evadido. Em 1845, F. J. N unes gratificava com $50 \$ 000$ réis, sem incluir as despesas, a quem capturasse o seu escravo M anoel Policarpio "fugido a 9 annos" que estava "em Villa N ova, trabalhando pelo offício [de carpinteiro] como liberto, eas vezes volta a villa deM acapá" (TrezedeM aio, 22/01/1845, p. 03).

Entretanto, asfugas de escravos não cessavam, provocando reações por parte das autoridades governamentais sumamente preocupadas com a manutenção da ordem social. N este período, a freqüência com que se criava ou al terava a legisl ação de controle erepressão aosmovimentos dos escravos, visando ao combate e à destruição dos mocambos ou, então, a própria coibição das evasões escravas do domínio senhorial, indicam a própriaineficácia das mesmas. Por outro lado, não havia outras alternativas viáveis aos guardiães da hierarquia social e preservação do direito de propriedade, senão a pronta repressão policial ao menor sinal de rebeldia escrava, como fica claro no ofício da presidência da província enviado à autoridade policial, publicado nas páginas do TrezedeM ai o, em 16 de dezembro de 1843:

Constando da parte, queV mc. medirigio no dia 7 do corrente, ter sido preso o preto escravo Eugenio por haver insultado e ameassado a patrulha com uma faca; ebem assim os pretos Sabino, eEmiliano por motim e desordem com tentativa de ofenderem um soldado da polícia provincial tendo-se eva- 
dido outro preto a aquelles de nome Fiel $M$ achado, e não convindo consentir que os escravos por um momento que seja deem provas de ousados e insubordinados, devendo antes ser prompto o seu castigo para exemplo dos outros, cumpre que Vmc. em similhares casos faça castigar correcionalmente com assolte os escravos que deliquirem usando de toda a severidade que é só o que é capaz de conter a gente demoralisada, e sem educação, e evitando-se processá-los sempre que for possível, porque com os processos sofrem mais seus snrs., e a demora do castigo influe sobre os outros (Treze de M aio, 16/12/1843, p. 01. [grifos meus]).

Em outro momento, 28 de julho de 1848, o presidente da província reafirmava a necessi dade da chefatura de polícia em ter todo cuidado com possíveis agitações políticas por parte dos escravos, realizando todas as averiguações e diligências neste sentido, levando em consideração a situação do país que, por si mesma, exigia redrobada vigilância e punição imediata aos suspeitos de amotinação e quebra da ordem:

Em resposta ao ofício de $V$ mce. datada de ontem tenho a dizer-lhe, que proceda com a maior severidade a respeito do escravo Bento procedendo a todas as possíveis diligências e indagações, a ver se pode descobrir-se algum plano ou tendência subversiva em relação ao melindroso assunto, em que parece vai tomando parte a escravatura, e principalmente procurar descobrir se há al guns agentes ou emissários estrangei ros, que tratem de propagar ideias perigosas entre os escravos. D esconfie do mal que atacou subtamente o escravo, pois tudo me inclina a crer que é simulado. Finalmente quando nada se descubra, deve ser o pardo Bento severamente castigado na cadêa, e entregue a seu senhor, para o mandar immediatamente para al gumas da províncias do sul.

V mce. terá a seu cuidado a maior vigilância sobre a escravatura, e sobre certos estrangeiros suspeitos, e previno-o que por notícias vindas particularmente no último vapor, as mesmas idéias vão lavrando em várias outras províncias, e até na capital do império. ${ }^{4}$

Q uais idéias perigosas estavam sendo propagadas entre os escravos, inclusive pelo pardo Bento? Embora o documento nada afirme em detaIhes, não é difícil imaginar que se tratava do tema da liberdade da escravaria. N esta perspectiva, a suspeita sobreagentes ou emi ssári os estrange roscapazes deinfluir sobre a escravatura e subverter a hierarquia social, indica as preocupações dos homens da lei com a má influência das pressões britânicas 
pela abolição do tráfico junto à população escrava, caso não fosse mero preconceito da autoridade governamental contra os escravos, achando que os negros não fossem capazes de pensar e agir por conta própria. D equalquer forma, a proximidade da região amazônica com o C aribe e a sua vizinhança com as G uianas, particularmente a G uiana Francesa, aumentava significativamente os temores das classes proprietárias em relação aos contatos do escravos paraen ses com prováveis agentes ou emi ssári os estrange ros reais ou imaginários. Afinal, desde o período colonial, as fugas de escravos aconteceram em ambos os sentidos entre as G uianas, não sendo incomum a circulação das notícias e idéias francesas prontamente associadas ao abolicionismo na boca dos cativos do lado de cá da fronteira, particularmente aquelas que davam conta do processo de abolição da escravidão no território francês, em 27 de abril de 1848. ${ }^{5}$ Lembre-se que, em Belém, somente al guns meses depois da libertação dos escravos franceses, o escravo Bento fora preso, muito provavelmente castigado e exilado para o sul do império, sob suspeita de envolvimento em algum plano ou tendência subversiva entre os cativos. $\mathrm{N}$ ão foram vãs, portanto, as precauções das autoridades policiais nesta época, como bem demonstra os episódios envolvendo o escravo José Antônio.

Em 28 de julho de 1848, o presidente da província havia determinado que 0 chefe de polícia mandasse recolher "à cadêa e immediatamente castigar com 200 açoites o escravo das fazendas nacionais José Antônio, por ameaçar com uma faca ao negociante $M$ anoel da Silva Ribeiro, e proferir palavras subversivas e perigosas nas circunstâncias actuais, (...), devendo o dito escravo depois de castigado, ser entregue amanhã ao commandantedo vapor Pernambuco para seguir no dito vapor". Jeronymo Francisco Coelho, presidenteprovincial, ainda recomendava que "antes do castigo cumpre que se faça os necessários interrogatórios a vêr se al guma coisa se revela sobre as i dé as que vão grassando sobre a escravaria". As palavras subversivas e perigosas proferidas por José Antônio, em resposta as repreensões que lhe fizera o português M anoel da Silva Ribeiro, foram "não ter medo de quem o governava pois que sabia o caminho de C ayena, onde o podião ir buscar". ${ }^{6}$ Em outras ocasiões, as palavras de José Antônio apenas indicariam o constantefluxo e refluxo de escravosfugidos entreas duas 
regiões limítrofes, muitos dos quais recapturados e repatriad os pelas autoridades de cada lado. Entretanto, nas circunstâncias actuais, somente alguns meses após a abolição do trabalho escravo na Guiana Francesa, em meio às pressões britânicas e às notícias ainda recentes de rebel dia escrava nas Américas eno próprio Brasil, as ditas palavras proferidas por qualquer escravo adquiriam significados políticos assustadores ao domínio dos senhores.7

Considerando o teor da documentação policial da época, transcrita acima, parece-nos realmente que os trabal hadores cativos não perdiam de vista o debate político à sua volta, em torno das questões relativas à proibição do tráfico negreiro eaos rumos da escravidão no Brasil, fazendo as suas próprias aval iações da conjuntura do país e levando em conta as notícias do estrangeiro, particularmente em região de fronteiras como a Amazônia. N este sentido, por exemplo, publicava-se denúncia no jornal 0 Planeta dizendo que, nas ruas da capital paraense, grande número de escravos agrupados nos cantos, nas praças, nas portas das tabernas, costumavam ficar ocupados "tratando da política do país", aumentando o espanto dos senhores quenão cansavam de clamar pela repressão policial: "C ontinuam os clubes de escravos em vozerias pelas tabernas e esquinas das principais ruas desta cidade; recomendamos aos srs. inspetores de quarteirões cumpram com seus deveres na parteque diz respeito" (0 Planeta, 27/11/1851, p. 01). $\mathrm{N}$ a verdade, a temeridade em relação às formas políticas de luta e resistência dosescravos, também significava um profundo descontentamento com a incapacidade governamental em cumprir o exercício de medidas de repressão e de controle social das classes trabalhadoras, sofrendo as autoridades as críticas das classes agrícolas e proprietárias que exigiam as "necessárias providências, capazes de atalhar o prezente, e prevenir o futuro mal" (0 Velho Brado do Amazonas, 17/06/1851, p. 04).

D e um lado, os reveses das forças policiais provinciais em combater os mocambos nas matas, não conseguindo impedir a existência e disseminação dos mesmos; de outro, o processo contínuo e crescente das fugas de escravos no período de 1840/1860, faziam com que a hegemonia das classes proprietárias fosse assombrada por uma "dolorosa recordação": a C abanagem. $\mathrm{Na}$ época, as lembranças que ficaram da participação escrava no movimento cabano não deixavam descansar o medo das classes proprietá- 
rias e agrícolas acerca da subversão escrava voltar a acontecer, caso não fossem mantidas severas políticas de controle social. N este sentido, embalados pelas "amargas lembranças" da C abanagem, o fantasma da revolução negra ressurgia sob o espectro do haitianismo. Em 1854, a chefatura de polícia comunicava ao presidente da província que a continuidade da inoperância das autoridades públicas e "a fuga em grande escala dos escravos" seriam as principais causas para que a tranqüilidadee a ordem pública estivessem "abaladas até seus fundamentos". D izia ainda mais a correspondência policial acerca das fugas de escravos: " ...esta planta a desolação por toda parte, e o receio em todos os corações, por ser tamanha a quantidade de negros fugidos, que se teme a cada instante nos venha acontecer o que aconteceu no $\mathrm{H}$ aiti". ${ }^{8}$ Embora escrevendo em 1854, o chefe de polícia paraense referia-se à insurreição dos escravos da colônia francesa de São Domingos, em fins do século XVIII, atual $\mathrm{H}$ aiti, demonstrando-nos 0 quanto esta revolução negra havia causado temor nas classes senhoriais de diversas partes das Américas até pel o menos meados do século XIX, quando defrontados com a rebeldia de seus escravos.

N a verdade, o medo senhorial da revolução escrava, "por ser tamanha a quantidade de negros fugidos", indica-nos perfeitamente como as próprias fugas não representavam apenas prejuízos econômicos aos senhores. Lado a lado com a quebra da disciplina nas senzal as, fragilizando as políticas cotidianas de domínio dos senhores, havia al go a mais: as fugas permitiam aos escravos entrel açar teias de intercâmbios entre as diversas regiões nacionais e estrangeiras constantes da divisão geopolítica da Amazônia, forjando uma tradição de lutas cadenciadas pela circulação de informações e estratégias, realimentando o sonho da liberdade. VicenteSalles, por exemplo, chama a atenção que desde o século XVIII as fugas de escravos na região amazônica ocorreram em ambos os sentidos da fronteira entre as G uianas Francesa e o Brasil, não sendo incomum negrosfugidos de C aiena buscarem asilo em Belém evice-versa, ainda que muitas vezes fossem repatriados pelas autoridades da cada lado (1988:221-222). Assim sendo, por meio dos fugitivos ligavam-se os mundos da escravidão existentes no Brasil, nas $\mathbf{G}$ uianas e no Caribe, fazendo ver ao senhores que $\mathbf{o} \mathbf{H}$ aiti não era longe daqui. 


\section{Histórias de liberdade nas fronteiras da Amazônia Setentrional}

O scontatos interétnicos na Amazônia, envolvendo brancos, negrose índios, desde a época colonial forjaram as suas próprias fronteiras à revelia dostratadosinternacionais, permitindo não somente as trocas comerciais, como intercâmbios de experiências einformações tão necessárias à própria sobrevivência dos mocambos e ao sucesso das fugas de escravos. Além disso, a partir das relações interétnicas com as diversas nações indígenas, os mocambeiros e fugitivos acabavam estabelecendo comunicação com seus pares do outro lado da fronteira, particularmente os bush negroes(FU NES, 1995:159-169; SALLES, 1988:231-239). N as últimas décadas do século XIX, por exemplo, João Barbosa Rodrigues, em sua obra Expl oração eEs tudo do Valle do Amazonas, descrevendo os mocambos da região do rio Trombetas, afirmava sobre os contatos dos mocambeiros com as nações indígenas que: "Por intermédio dos Arequenas negociam com os índios Tunayanas que habitam próximo à confluência [dos rios $\mathrm{M}$ ahu e Capu, quando começa a denominar-seTrombetas], não longe dos C hamarumás, que a seu turno tratam com os Pianá-gatós, estes com os D rios e mocambistas de Suriname". Portanto, em que pesem os conflitos com determinadas etnias, os mocambeiros estabel eciam convivência sem maiores problemas com outros grupos humanos nativos da região, construindo seus espaços de liberdade nas matas da região, conforme testemunhava Barbosa Rodrigues: “O s Pianá-gatós, Tunayanase C hamarumás, costumam descer até os mocambos, e mesmo parte da tribo dos Pianá-Gatós, desceu e se estabeleceu nas cabeceiras do rio Aripecuru" (apud SALLES, 1988: 237).

$\mathrm{H}$ á, portanto, uma complexa rede de intercâmbios que, envolvendo diversas etnias indígenas, permitia o contato entre mocambeiros, escravos e pessoas livres de diversas regiões e áreas fronteiriças da Amazônia brasileira. N este sentido, é possível pensar uma tradição de lutas escravas marcada não somente pela circulação de mercadorias, mas particularmente conhecimentos e notícias entre os mundos da escravidão da Amazônia brasileira, Guiana Francesa, C aribeeAmérica espanhola, tal como a figura do bumerangue proposto por Peter Linebaugh em seus estudos acerca do 
mundo atlântico, no qual sugere que nos séculos XV II-XVIII as idéias revolucionárias das classes trabalhadoras da Inglaterra atravessaram o oceano em direção ao continente americano, através dos passageiros e tripulantes dos navios mercantes, lançando as suas sementes no novo mundo, constituindo-se parte da cultura dosmovimentosafro-americanos que, por sua vez, acabavam retornando à própria Inglaterra, fazendo-se presente no processo deformação da classe operária inglesa. Aliás, o próprio Linebaugh já sugeria análises similares para a compreensão da cultura das classes trabalhadoras no Brasil. ${ }^{9}$

N este contexto, determinados escravos em suasfugas, informadospela circulação das notícias estrangeiras e intercâmbios de experiências, acabavam fazendo com que seus senhores levantassem suspeitas de que fossem foragidos em busca da liberdade em outros países. Em junho de 1852, Antônio T heodoro da Silva Penna achava provável Jesuíno ter fugido "em companhia dos escravos Saturnino e Pedro com destino de transportar-se à H espanha" (0 Publicador Paraense, 28/06/1852, p. 04); em dezembro de1853, M anoel Roque Jorge Ribeiro anunciava que seu cativo Theodoro "há dias" não Ihe aparecia e, como não constava "que tenha sido visto por pessoa alguma nesta cidade[Belém]", achava possível que "o dito escravo se evadisse com o fim de passar para outra província, ou mesmo para algum país estrangeiro" (Treze de M aio, 29/12/1853, p. 06). Embora o senhor não informasse qual seria o país estrangeiro, talvez T heodoro, como tantos outros fugitivos, houvesse escolhido refugiar-se na Guiana Francesa.

Sobre as fugas de escravos da província paraense rumo à colônia francesa, embora já se tenha dito que ocorriam desde o período colonial, podese dizer queadquiriram novos significados durante o século XIX. Logo em seus primeiros anos houve a ocupação militar luso-brasileira da Guiana Francesa (1809-1817), em conseqüência do estado de guerra entrea França de N apoleão ePortugal (VIAN N A, 1900:246; CARD O SO , 1984:145). Assim sendo, mesmo que momentaneamente, os dois lado do 0 iapoque ficavam submetidos à autoridade luso-brasileira, permitindo maior abertura dos canais de comunicação entre uma e outra parte, fazendo chegar mais facilmente aos ouvidos dos escravos paraenses as informações relativas àquele território que, até então submetido ao governo francês, fora 
posteriormente devolvido aos franceses. Lembre-se, por exemplo, o item VI dos termos de capitulação das tropas francesas derrotadas na G uiana, relativamente ao destino dos escravos guianenses que lutaram na refrega tanto ao lado dos invadidos quanto dos invasores em troca da liberdade. Segundo Cardoso, o referido documento "rezava que todos os negros seriam desarmados, e que aqueles que haviam sido alforriados pelas tropas luso-inglesas deveriam sair da G uiana, onde certamente setornariam, caso ficassem, um elemento de perturbação social", sendo tais libertos embarcados para o Pará (1984:157). N ão é difícil imaginar que, desembarcando compulsoriamente em Belém e submetidos às condições de vida e trabaIho comuns aos demais segmentos das cl asses subal ternas paraenses, os exescravos franceses firmassem relações de convívio com pessoas pobres livres e escravos, tornando-se informantes acerca das condições de vida em sua terra de origem.

$\mathrm{N}$ o que diz respeito aos efetivos militares disponibilizados na invasão e ocupação do território francês adjunto ao Grão-Pará, quando do seu retorno ao território paraensetambém épossível percebêlos como difusores de toda sorte de informações sobre a região e os guianenses do outro lado do O iapoque. O ra, durante a conquista e domínio da Guiana Francesa, com "exceção dos marinheiros ingleses e alguns oficiais luso-brasileiros, 0 grosso da tropa eram índios e mestiços"(CARD 0 SO , 1984:154), portanto, o retorno ao torrão natal implicava sua reinserção junto à população mestiça e negra do Pará, municiando-a com as suas impressões sobre a colônia da França, haja vista a própria composição étnica e social da soldadesca. D e fato, em seus preparativos militares, face a um possível conflito com os franceses de Caiena, o governador levantou "duas Companhias de M ilicianos Artilheiros na classe dos homens negros e pardos com subordinação ao mando do Commandante do Corpo deArtilharia de Linha", ainda em 1808 (BAEN A, 1969:274); no ano seguinte, posteriormenteà conquista luso-brasileira da Guiana Francesa, a guarnição de Belém recebeu reforço da "Tropa de Pernambuco", composta por oitocentos soldados "abastecidos do competentearmamento", entreosquais "uma Companhia dePardose de outra de Pretos", visando não somente sua defesa contra possíveis ataques inimigos, mas a própria manutenção da ordem e da tranqüilidade 
públicas em face da carestia de farinha na capital paraense, cuja falta eeminente elevação de seu preço exaltava os ânimos da população (BAEN A, 1969:278). Assim, não era nada incomum a presença de negros emestiços no seio das tropas lotadas na região, cujas companhias, sendo enviadas em missão ao estrangeiro, traziam na volta as experiências e conhecimentos assimilados no contato com a sociedade francesa da G uiana, socializandoos entre seus pares.

A desocupação da Guiana Francesa pelas tropas luso-brasileiras, em razão do tratado de 28 de agosto de 1817, fazia com que a dita colônia fosse reincorporada aos territórios da França. Entretanto, tal fato não significava a pacificação das relações entre as duas regiões fronteiriças, continuando os conflitos em torno do estabelecimento definitivo dos limites entre as mesmas, tanto que, em 1836, soldados franceses penetraram no Amapá fundando uma fortificação militar, em cuja sombra "logo se localizaram cerca de cem pessoas, vindas da G uiana, para dar início a uma tentativa de colonização"(REIS, 1982:90). 0 governo de Caiena logicamente procurava tirar vantagens das condições em que se encontrava a província paraense, mergulhada nas convulsões sociais da C abanagem, lançando as sementes de ocupação militar e colonização civil do território brasileiro há muito tempo pretendido pelo governo francês. Em face do protesto das autoridades governamentais brasileiras, os invasores justificavam sua ação militar em razão da necessidade de proteção de suas fronteiras potencialmente ameaçadas pelos distúrbios da guerra civil no G rão-Pará, alegando o caráter provisório da referida presença em terras amapaenses. Em torno dequatro anos ficaram os franceses em terras da G uiana Brasileira, retirando-se somente em 10 de julho de 1840, porque não haviam conseguindo consolidar suas posições. $N$ esta época os últimos cabanos estavam sendo derrotados e presos pelas tropas legalistas, findando-se a experiência revoIucionária na Amazônia, fazendo com que a reação brasileira contra a investida francesa tomasse vulto. Assim, em 5 de maio de 1840 fora fundada a colônia militar Pedro II, localizada à margem direita do A raguary, distante da "boca do mesmo Rio 36 léguas, e 550 braças aproximadamente" (Treze de M aio, 30/05/1840, p.22). 0 referido núcleo colonial, cuja instalação visava à defesa militar e à colonização do território amapaense 
frente ao avanço francês, exemplificava a firme posição do governo brasileiro em não ceder parte al guma da região insistentemente pleiteada pela França. Portanto, sob o arbítrio inglês, os franceses recuaram, satisfazendo os interesses do governo imperial brasileiro.

Todavia, as pendências territoriais em torno da G uiana Brasileira, envolvendo a França e o Brasil, ainda estavam longe de seu epílogo. Comentando o fato, escreveu Arthur Vianna: "A França, que evacuara o seu posto sem impor condições, tratou, em 1841, de tirar da sua conducta vantagens de monta, e o conseguiu; 0 accôrdo de 5 de julho de 1841 declarou neutro o território comprehendido entre o Amapá e o 0 yapoc, quando os direitos do Brazil sobre tal região eram incontestes e inexpugnaveis" (1900:247). 0 estabelecimento da zona neutra, denominada Contestado, sem dúvida nenhuma representava uma vitória francesa, ainda que parcial e provisória. ${ }^{10}$ Por outro lado, a Z ona N eutra constituía-se em região aberta na qual escravos fugidos, réus da justiça e desertores encontravam abrigo, formando mocambos que, ao contrário dos demais local izados em outros pontos da província paraense, não foram combatidos sistematicamente pelas tropas de polícia e da Guarda $\mathrm{N}$ acional. Afinal, 0 envio de soldados ao Contestado em busca de fugitivos podia fazer vir à tona problemas diplomáticosentrefranceses ebrasileiros (SALLES, 1988:223). Percebe-se, então, como os efeitos da querelas entre os governos da França e Brasil, acerca de suas fronteiras na região das Guianas, mesmo que involuntariamente, forjavam as condições favoráveis às fugas de escravos em direção ao 0 iapoque, especificamente rumo ao outro lado do rio. $M$ as, mesmo que os franceses pactuassem com toda sorte de fugitivos homiziados no C ontestado, buscando apoio às suas preten sões territoriais, inclusive durante sua ocupação da área (1836-1840), pouca importância teria a referida conjuntura caso os escravos não fizessem as suas próprias leituras da geopolítica daquela área de fronteiras, enquanto possível campo de atuação em busca de suas liberdades.

0 movimento de fugas de escravos para a Guina Francesa, existente desde o período colonial, não somente ganhava novos contornos e significados como aumentava a sua freqüência nas décadas de 1840 e 1850, particularmente quando o cativeiro fora abolido nas possessões francesas em 
1848. Em abril de 1851, por exemplo, 0 Velho Brado do Amazonas, noticiando "a recente deserção dos escravos da vila de M acapá para Caiena", comentava que:

D e há pouco tempo a esta parte que em tôdas as conjunções de lua se notava em M acapá o desaparecimento de escravatura em grupos de cinco, de dez e até doze indivíduos; e porque semelhante deserção crescesse, despertaram a curiosidade e interêsse dos respectivos senhores para descobrirem 0 modo por que tais fugas se praticavam, e o destino que tomavam os fugitivos; e feitas tôdas as pesquisas a respeito, descobriu-se que os escravos se evadiam costa abaixo, para irem demandar o M apá, edaí buscarem guarida em terras de Caiena (O Velho Brado do Amazonas, 24/04/1851, pp. 01-02).

Asnotícias editadas pelaimprensa paraense, acerca das expressivasfugas de escravos em direção ao território da colônia francesa, no período posterior ao término da escravidão na mesma, indica-nos perfeitamente a leitura política feita pelos escravos, a partir do processo de intercâmbio de informações havido entreos dois lados da fronteira, fazendo com queas próprias fugas adquirissem novos significados, embalados pela esperança da obtenção da liberdade em Caiena. Assim sendo, é bastante ilustrativa a história que segue.

0 jornal 0 D outrinário, em sua edição de 30 de novembro de 1848, noticiava aos seus leitores 0 desfecho, ainda que feliz, de uma verdadeira tragédia. Fundeada no porto deB elém, a escuna francesa Anna, deC aiena, trouxera consigo os sobreviventes da tripulação do brigue-escuna brasileiro Argos que, pertencente aos srs. J. D. C astro e C $\underline{a}$ do M aranhão, havia naufragado apósquarenta dias deviagem entreC aienaeParnahiba. Segundo o relato do jornal, na hora do naufrágio, "a tripolação, composta de 15 pessoas, metteu-se na lancha com al gumas provisões e o dinheiro do carre gamento do navio somente". D urante 29 dias os náufragos ficaram entre gues à própria sorte: "na noite de 08 de setembro passou pela lancha dos infelizes nauffragados uma barca americana ou ingleza; pediram soccorro, mas em vão". N este período, três homens acabaram mortos de sede, sob o peso de "crueis padecimentos", atéque "houverão vista do C abo de 0 range, e seguiram para Cayenna, aonde o governador, as authoridades e toda a população a porfia se desvelaram em dar toda a consolação e agasalho a esses novos concidadãos". A contece que: 
$\mathrm{N}$ as vesperas da sahida do capitão do navio naufragado para este porto [Belém], evadiram-se 3 escravos pertencentes ao mesmo navio, procurando ficar em Cayenna, por se supporem livres, mas o governador os mandou prender emetter abordo da escunaAnna, declarando queo governo daquella colônia não consentia a entrada de pretos, embora livres, ou escravos ( 0 D outrinário, 30/11/1848, p. 01).

Embora frustrados em seus planos de liberdade, tais escravos exemplificam perfeitamente o processo de apreensão e reinterpretação da realidade política à sua volta, pois, com toda certeza, apostavam conseguir escapar ao cativeiro, refugiando-se na colônia francesa que há pouco tempo havia abolido a escravidão. Porém, também foi-Ihes ensinado como o lado francês da floresta não se constituía um território livre ao ingresso de negrose mestiços, fazendo-se necessário continuar penetrando no mesmo por meio de outros caminhos clandestinos já trilhados há bastante tempo.

Por outro lado, os ditos escravos trabalhavam no navio naufragado, sendo marinheiros que, capturados e repatriados, voltavam ao solo brasileiro, com destino ao $M$ aranhão, aportando em Belém. N esta viagem de regresso, portanto, não só traziam consigo o insucesso de suas experiências tranर्sformadas em lições transmitidas aos camaradas da escravidão, como repassavam outras notícias e informações, fazendo-as circular nas senzalas.

D e fato, não era incomum o emprego de trabalhadores escravos em navios, fazendo parte da tripulação, particularmente na Amazônia. Em 1854, o presidente Sebastião do Rego Barros, em sua fala dirigida à Assembléia Legislativa Provincial, noticiando sobre a navegação interior e fluvial no Grão-Pará, dizia que se achavam matriculados "na C apitânia do Porto 477 embarcações de diversos portes desde pequenas canôas até escunas, representando 4:667 toneladas e tripuladas por 2:621 pessoas livres e 211 escravos", embora fosse reconhecido o caráter incompleto do referido quadro estatístico;'11 já em 1859, o tenente-coronel M anoel deFriaseVasconcelos, na segunda sessão da 11 a legislatura da Assembléia Provincial, dizia aos nobres deputados que: "Segundo o mappa fornecido pelo C apitão do Porto, nas 7 comarcas da província consta[va] existir em effectiva navegação 351 canôas, e outras embarcações, inclusive 5 vapores da Companhia de $\mathrm{N}$ avegação e C ommércio do Amasonas, com uma tonellagem de 7:030 
e tripuladas por 2:160 individuos dos quais 2:035 são livres e 125 escravos" ${ }^{12}$

D a mesma forma, a circulação de fugitivos nas embarcações furtadas aossenhores, intercambiando informaçõese experiências pelasmargens dos rios com os diversos segmentos das populações ribeirinhas, também favorecia a difusão das leituras políticas dos escravos acerca da realidade do país e nações vizinhas, avaliando tais conjunturas como favoráveis ou não em suas lutas contra o domínio senhorial.

\section{Outros caminhos de liberdade: as fugas de escravos e os mocambos.}

Embora vendidos e comprados em fuga, uma vez que, mesmo fugidos, os cativos não perdiam a sua condição de propriedade de determinada pessoa, podendo ser negociados por seus senhores, os escravos fujões jamais constituiriam o exemplo de trabalhadores que, na mentalidade senhorial, havia deexistir sob o peso do cipó derêgo, em suas labutas cotidianas; particularmente no período em questão, no qual o crescente movimento de fugas de escravos parecia elevar o medo senhorial da revolta escrava, quer imaginário ou real. N este sentido, no jornal Treze de M aio, 0 tenente-coronel Anselmo J oaquim da Silva, senhor de escravos em fuga, publicava o seguinte anúncio:

Q uem tiver equiser alugar ou vender, algum prêto, que seja robusto para o serviço, fiel einteligente, enão seja bêbado, ladrão nem fujão; dirija-seà casa do tenente-coronel Anselmo Joaquim da Silva, na Rua da Paixão, canto da Travessa de S. M atheus, ou anuncie por esta folha para ser procurado, etratar-sedo ajustecaso agradeao comprador (TrezedeM aio, s/data-1847, p.12).

$\mathrm{N}$ a verdade, ficava bastante difícil aos senhores impor disciplina aos seus trabalhadores escravos, enquanto fosse possível aos mesmos continuar fugindo, embora capturados, castigados e presos em ferros. Entretanto, coibido o caminho das fugas, muitas vezes o protesto político dos escravos adquiria novos significados e espaços de ação, sob a forma de crimes contra a pessoa do senhor. Em julho de 1850 fugiu ao tenente Jozé Bernardo Santarém um escravo, levando sua roupa de trabalho e um Baú com a 
melhor roupa que possuía (0 Planeta, 08/08/1850, p. 03); em novembro fugiram outros quatro escravos: M anoel Ramos D oce, Luiza e o casal Antônio e Felicia, do engenho Santo I gnácio em M agoary, diminuindo-se a força de trabalho disponível aos serviços do tenente Jozé Bernardo G uimarães (0 Publicador Paraense, Belém, 21/01/1851, p. 04); em 1851, na noite de vinte e um de julho, o referido senhor "foi barbaramente assassinado a golpes de fouce roçadoura...., por seu próprio escravo Antônio", informando o jornal 0 Correio dos Pobres que: "O funesto acontecimento teve lugar na ocasião em que o sñr. Santarém estava ral hando com uma preta forra pela assuada que fazia no rancho a essa infeliz hora" (C orreio dos Pobres, 25/07/1851, pp. 02-03). Seria o escravo Antônio, autor do crime, o mesmo Antônio que havia fugido em 1850, em companhia de outros escravos de seu senhor?Talvez.

D e qual quer forma, este escravo matou o senhor na ocasião em queo mesmo não só procurava disciplinar seus escravos, como também outras pessoas, ral hando com uma preta forra pela assuada quefazia durantea noite. Antônio, portanto, usando seu instrumento detrabalho protestara matando o senhor que, mesmo fora do horário de trabalho, coibia as brincadeiras dos escravos e seus camaradas, querendo impor-Ihes subserviência ao governo senhorial.

Em 31 de julho de 18510 Correio dos Pobres noticiava as providências do chefe de polícia, afirmando que: "à vindicta pública faz quequanto antes o réo exhale no patíbulo os últimos al entos de uma vida tão perigosa à sociedade" (Correio dos Pobres, 25/07/1851, pp. 02-03). As palavras do jornal solicitando extremado rigor e severidade na aplicação da pena capital, previstana legislação, emergia do medo das classes proprietárias em face das manifestações de protesto dos diversos segmentos das classes subalternas, particularmente o temor da rebeldia escrava. Alguns anos antes, por exemplo, $\mathrm{H}$ erculano Ferreira Pena, presidente da província, ainda que expressando as suas ponderações, reconhecia as apreensões dos senhores:

O shabitantes devários districtos continuão a queixar-sede offensas eameaças feitas por escravos fugidos, vadios, desertores, eoutros criminosos, que evadindo-se das prisões, e subtrahindo-se ás vistas da autoridade, vivem acoutados em lugares pouco povoados, ondea força pública não ésufficiente 
para reprimir seus insultos; mas convém notar-se que d'entre os crimes comettidos por essa gente, que pertence sem dúvida á infima classe da sociedade, nenhum tem chegado ao meu conhecimento, que seja digno de especial menção por sua atrocidade, ou por quaesquer circunstancias extraordinárias de que fosse revestido. ${ }^{13}$

0 número significativo de escravos em fuga, fragilizando as formas decontrole social dos trabal hadores cativos, acabava favorecendo a quebra da disciplina necessária ao exercício do domínio senhorial, permitindo compreender a raiz dos temores e apreensões das classes agrícolas e proprietárias que, reclamando a coibição dasfugas, solicitavam o combateaos quilombos:

É sabido que existem na província quilombos consideráveis, em que vivem acoutados não somente escravos fugidos, mas também desertores, criminosos, malfeitores detodo o gênero. Segundo as informações que tenho colhido, o número de escravos que nêles existem é superior a 2 mil. Fazendeiros possuidores de escravos têm-me comunicado o estado anormal, em que a existência conhecida de tais quilombos os têm colocado, impossibilitando a disciplina, pelo fundado receio da fuga, e acoutamento certo nesses lugares, onde os fugitivos encontram segurança contra qualquer tentativa de apreensão... ${ }^{14}$

O s fazendeiros, como tanto outros cidadãos, sabiam que os mocambos funcionavam como verdadeiros pólos magnéticos sobre a escravaria, seduzindo-os do serviço dossenhores em prejuízo das rendasnacionais, assentadas no trabalho agrícola. Assim sendo, os proprietários não exageravam em suas críticas ao governo provincial, por sua ineficácia na guerra aos mocambeiros, na medida em que as fugas de escravos, ocorridas em grupos, muitas vezes redundavam na formação de quilombos ou, então, engrossavam outros já existentes há bastante tempo. N este sentido, vários escravosem fuga refugiavam-senas regiões habitadastradicionalmentepelos mocambeiros: na região do rio $M$ ojú, no igarapé C abresto, encontravamse acoutados os escravos Ricardo, I gnácio, Joaquim Facundo, Joaquim, Theodosio, Ezequiel, Thomé, Zacarias, Libânio e Amancio, pertencentes a Raymundo Pereira da Silva Lima, morador no distrito de Anapú (0 D outrinário, 03/01/1849, p.04); Carlota M arcellina, de Antônio Rodri- 
gues dos SantoseAlmeida, residenteem Belém, fugida em março de 1851, também existia no dito igarapé do Cabresto ( 0 Velho Brado do Amazonas, 08/02/1852, p. 04); Tamciano, por sua vez, encontrava-se na mesma localidade, "acoutado por hum seringueiro" (0 Velho Brado do Amazonas, 08/ 02/1852, p.04); Izidoro, de Raimundo Pereira Silva Lima, em sua fuga diziam "andar para os arrabaldes da fazenda C abresto erio Arauaia, etambém pelo rio M ojú" (Treze de M aio, 17/12/1845, p. 04).

Segundo Vicente Salles: "A região infestada de mocambos era as do rios M ojú, C apim, Acará, e a área próxima do Baixo Tocantins. 0 M ojú sobretudo, onde os negros, ciente da existência daqueles mocambos, estavam muito agitados", embora Salles reconheça a existência de outros diversos quilombos nas regiões do Baixo Amazonas; da Zona Guajarina; de M acapá; e, de Turiaçu-G urupi; nos quais muitos escravos buscavam asilo (1988:215). Na verdade, justamente nas zonas do território paraense em que se localizavam os contigentes mais significativos de escravos achavamse constituídos os seus principais mocambos, uma vez que os escravos fugidos de determinada região, embora pudessem evadir-se com destino a outros paradeiros, muitas vezes homiziavam-se nas mesmas áreas em que haviam vivido e trabal hado sob o governo de seus senhores. Assim sendo, a constituição dos quilombos não significava a marginalização dos fugitivos em relação à sociedade, pelo contrário, tornando-se negros aquilombados não perdiam necessariamente o contato com seus antigos senhores, enquanto estabeleciam toda uma rede de comércio e informações com demais segmentos da sociedade. Os escravos fugidos de Ó bidos (Baixo Amazonas), por exemplo, quando vinham à mesma não se furtavam da presença de seus senhores, mas encontrando-os pediam-Ihes a bênção, prontamente dada. D a mesma forma, faziam suas transações mercantiscom taberneiros e demais comerciantes, fornecendo-Ihes o tabaco, o breu, a sal saparrilha e outros produtos cultivados ou extraídos da floresta, em troca dealimentos, armamentos emunições. Entreuma compra daqui euma venda dali, falava-se da vida, contavam-se as novidades que as embarcações levavam e traziam pelos caminhos fluviais do vale amazônico. Os regatões, inclusive, tornavam-se importantes parceiros comerciais dos mocambos, muitas vezes prevenindo-os sobre expedições de combate en- 
viadas pelas autoridades, pois, mesmo sendo os quilombos inseridos na sociedade escravista não quer dizer que fossem aceitos e permitidos.

Entretanto, não somenteo elevado número de escravos em fuga, mas, particularmente, o tempo em que os fugitivos conseguiam ficar livres do serviço de seus senhores indica-nos ser muito freqüente a busca da liberdade nos mocambos, funcionando os mesmos como principais centros de convergência dosfugitivos. N a verdade, somentea partir da década de 1860 parece ocorrer um redirecionamento nas rotas de fugas de escravos em direção à cidade, no caso Belém (BEZERRA N ETO , 1993). N o momento, porém, retornando ao problema de duração de tempo da ausência dosfugitivos, há diversos casos registrados nos anúncios: em 04 deabril de 1849, J ozéH onorato da Silva M iranda prometia boas alvíssaras a quem Ihe apresentasse os cativos D omingos e Alexandre, foragidos há cinco anos (Treze deM aio, 07/12/1844, p. 03); ainda em abril, Lourenço C oelho de C astro declarava querer vender seu escravo em fuga, Sabino Antônio, ausente há oito anos (0 D outrinário, 26/04/1849, p. 08); em 1ํㅡㄹ de outubro de 1852, JozéÓ D 'Almeida dava cem mil-réis por escravo para quem viessea entregar-Ihe Vicente, Emigdio e Lourença, fugidos há dez anos (0 Publicador Paraense, 01/10/1852, p. 06).

A significativa duração do tempo de fuga dos escravos, numa escala de três até vinte anos de completa ausência, colocava a necessidade da repressão ao movimento de fugas de escravos também dar combate às práticas de acoutamento dos fugitivos que lhes permitiam, em mocambos ou não, viver como escravos em plena liberdade.

\section{0 "apoio fugatório": conflitos, solidariedades e fugas escravas}

D a mesma forma que os mocambos não se encontravam isolados, sendo muitas vezes inseridos nos circuitos comerciais das regiões circunvizinhas, ainda que duramente combatidos pelas tropas governamentais; os escravos em fuga também contavam com diversas teias de relações sociais capazes de favorecê-los em seu intento, lembrando que as mesmas forjavam-se e faziam parte dos mundos da escravidão. Assim sendo, o escravo L ourenço, segundo seu senhor, "em ocasião de ir vender bolacha, num 
taboleiro de pinho pelas tabernas desta cidade", havia fugido com "apoio fugatório" daquel es que "não sendo capazes de darem uma passagem por esmola a qualquer cidadão pobre, estão prontos a ministrá-la aos escravos que fogem aos seus senhores...... porque êstes se tornam semi-escravos de quem os apoia" (0 Diário do Gram-Pará, 09/07/1854, s/p).

0 "apoio fugatório" dispensado por segmentos da população livre, visando apropriar-se da força de trabal ho dos escravos em fuga, podia constituir-secomo resultado de acordos havidos entre as partes, permitindo aos fugitivos sob o serviço dos "novos senhores" conquistarem melhores condições de vida e maiores espaços de liberdade. 0 escravo Lourenço, por exemplo, foi capturado em companhia de M aria Balbina e Romualdo Vianna, sendo entregue ao seu proprietário que, indignado, clamava na imprensa: "são estes, os mais terríveis quilombos" (Treze de M ai 0, 25/07/ 1854 , p. 04). Em outras ocasi ões os fugitivos buscavam asilo junto aos seus antigos senhores, procurando reatar relações de domínio senhorial que, à revelia dos mesmos, foram quebradas pelas transferências da propriedade escrava entre os homens livres. Por exemplo, Aleixo de Tolosa vivia fugido no rio Guamá, "acoutado por Bernadina M aria da Piedade", sua antiga senhora (0 D outrinário, 26/05/1848, p. 04); da mesma forma, H onorato, Abel, Adjucto, Zebedeo, Vito e Alaryco, escravos de Julião da C osta Souza, existiam em fuga "em companhia da sobredita Bernadina M aria da Piedade, viúva de Joaquim Romano, irmão do annunciante[Julião da C osta Souza], e U mbelino Egidio N unes, genro da dita" (0 D outrinário, 26/05/ 1848, p. 04). N esta história é possível perceber disputas senhoriais envolvendo os bens deixados pelo falecido Joaquim Romano, que foram entregues ao seu irmão em detrimento da esposa. Entre tais bens, os escravos que não reconhecendo legitimidade na autoridade senhorial conferida a Julião da C osta Souza, fugiram em busca da antiga senhora.

O s escravos em fuga também podiam ser submetidos ao trabalho compulsório, sofrendo novas experiências de cativeiro, quer capturados ou acoutados por outros senhores, na medida em que as relações de domínio senhorial não prescindiam unicamente da validade legal de títulos de propriedade, porém impunham-se como práticas exercidas quotidianamente nos mundos da escravidão, a partir dos diversos significados atribuídos pelos 
próprios personagens envolvidos na trama social. N este sentido, Tomás Tavares Bastos, do Engenho deS. M arçal do Rio Arari, na ilha de M arajó, possuía três escravos "muito conhecidos, tanto nesta ilha como na capital do Pará", em fuga: Francisco, Simão e Boaventura; protestando "haver da pessoa ou pessoas que os açoitem e dêles se servirem, tôdas as perdas e danos, queem conseqüência da fugativer sofrido, eno caso demorteou aleijão que adquiram na dita fuga, tem de haver 0 anunciante um conto de réis (1.000\$000) por cada um, valor êste que dá segundo a estima que os tem; além disto os dias de serviço na razão de $1 \$ 000$ réis diários, e mais penas que a lei impõe aos acoutadores e sedutores de escravos al heios" (Treze de M aio, 17/04/1854, p. 04).

Entretanto, na rede de relações sociais construídas pelos escravos existiam outros nós que uniam os mesmos entre si e aos diversos segmentos das classes subalternas, constituindo-selaços de solidariedade compartilhados pelos fugitivos. N este sentido, em dezembro de 1850 Antônio e GuiIherme "fugiram com uma canôa vigilenga", sob a suspeita do seu senhor, $M$ anoel $G$ onçalves do R êgo, de que os mesmos encontravam-se "pelo districto de Chaves em M arajó, na fazenda da Santa Casa, acoutado por um prêto denome Ponciano" (0 Planeta, 26/04/1851, p. 04). Por sua vez, o escravo fugido Francisco fora "encontrado no rio Tapajarú em companhia d'outro escravo cafuz da mesma vila" (Treze de M aio, 29/07/1846, p. 06). Já A na I sabel escondia-se "em certa casa na rua D 'Alfama ondetem se acoutado por outras fugidas" (0 Publicador Paraense, 21/11/1849, p. 04).

$\mathrm{N}$ a verdade, embora pessoas de condições sociais diversas pudessem cometer o mesmo crime de acoutamento de escravos fugidos, desde fazendeiros até escravos, a repressão sobre os acoitadores não acontecia de forma semelhante, sendo reservado aos mais afortunados os processos judiciais, muitas vezes inconclusos, enquanto a prisão imediata impunha-se sobre os pobres livres, libertos e escravos. D esta forma, cadenciada por relações de poder, a aplicação da legislação penal fazia-se seletiva: em maio de 1858, por ordem do subdelegado do 2 distrito da capital, fora presa "a preta escrava Ângela, por acoutamento de escravos fugidos" (Gazeta O ficial, 15/05/1858, s/p.); em janeiro de 1859, o chefe de polícia da província mandou prender "a preta M aria, por acoutar uma escrava" (D iário do 
Commércio, 18/01/1859, p. 02). Também é interessante observar que, enquanto 0 acoutamento constituía-se em prática criminosa, a fuga do escravo em si mesma não era considerada da mesma forma, ainda que fosse combatida e recriminada pelos senhores e autoridades governamentais. $\mathrm{N}$ a verdade, a não criminalização da fuga podia representar a compreensão senhorial da mesma enquanto parte das relações sociais estabelecidas sob o regime da escravidão, essencialmente marcadas como relações diretas e pessoais entre senhores e escravos. D esta forma, os senhores, mesmo que reconhecendo as fugas escravas como instrumento de luta política de seus escravos, procuravam manter seus trabal hadores cativos sob o seu domínio, negociando com os fugitivos e castigando-os quando lhes era conveniente.

\section{A cumplicidade dos contrários: conflitos e camaradagem fazendo a escravidão}

Em 27 de setembro de 1850, o jornal 0 Velho Brado do Amazonas denunciava que o subdelegado da vila de Ó bidos, o bacharel Félix G omes de Rego, praticava "os actos mais indecorozos à dignidade do cargo público", informando que "entre [os] muitos, que quazi sempre pratica, distingue-se hum com que deu prolongado expectaculo no dia 29 de junho passado, capitaneando a hum bando de moleques, com o seu Bumbá!!". 0 jornal transcrevia o relato feito por certa pessoa da vila de Ó bidos, acerca do folguedo dos escravos denominado Boi-Bumbá, o qual sendo capitaneado pelo subdelegado de polícia, durante as comemorações da quadra junina, constituía-se nas razões de suas queixas encaminhadas à imprensa:

Eu quizera queessehomem, queduas vezes me prometteo arredar o D r. Rego da D elegacia, viesse ver o desprezo, o isolamento em q'está este seu protegido; quizera queviesse presenciar a sua loucura; quizera finalmente que viesse assistir ao acto menos condigno de huma autoridade, como foi o [que o] Dr. Rego praticou na noite de 29 dejunho, pondo-se a frente de hum bando demoleques com seu - Bumbá - designando lugares onde devião dansar, e tendo o descauço de ameaçar com cadeia a huma porção de rapazes da melhor mocidade de Ó bidos, só porque lançavão carretilhas sobre os dire- 
tores do - Bumbá - que erão seus escravos CASEM IRO e CLAU DIN 0 (0 Velho Brado do Amazonas, 27/09/1850, p. 03).

0 Velho Brado do Amazonas também pedia a exoneração do subdelegado de Ó bidos, lembrando as inconveniências para a preservação da ordem social caso a presidência da província mantivesseo bacharel ebrincante de boi-bumbá, Dr. Félix G omes do Rego, em suas funções: "Q ue moralidade, que polícia, que segurança individual, e de propriedade pode haver na vila d'Ó bidos, onde o D elegado, em lugar de curar de tranqüilidade pública, de garantir sossego à população, capitanêa hordas de negros escravos, em cujo número se achão al guns seos, dando expectaculo, eservindo de irrisão pelas ruas publicas da Villa?" (0 Velho Brado do Amazonas, 27/09/1850, p. 03).

Tal história, na verdade, mais uma vez permite-nos perceber como os espaços sociais na escravidão muitas vezes não detinham fronteiras precisas, havendo bacharéis que, ocupando cargos públicos importantes, organizavam e lideravam folguedos de escravos nos logradouros públicos. Por outro lado, a participação dos homens da lei nas brincadeiras dos trabal hadores escravos, ainda que no período de festas na quadra junina, causava espanto no seio das classes proprietárias sumamente preocupadas com a preservação da hierarquia social eda ordem pública, particularmentenuma época marcada pelas recentes e "amargas lembranças" da cabanagem eque, ainda, vivenciava a insubordinação dos cativos por meio do processo cada vez mais crescente das fugas de escravos.

É verdade que as queixas contra diversas autoridades públicas, acusadas de comportamentos indignos e incompatíveis com a honra de seus cargos, encontravam-se inseridas no contexto político das disputas entre os partidários dos grupos liberais e conservadores. C ertas denúncias, publicadas nas páginas dos jornaiscontratal ou qual ocupante de determinada função pública, refletiam os próprios compromissos políticos desta ou daquela folha noticiosa em relação aos grupos sociais situados na oposição ou encastelados no governo provincial. O Treze de M aio, por exemplo, vinculado aos segmentos conservadores, surgiu no início da década de 1840 sob a condição dejornal oficial, publicando as falas do poder provincial; 0 Correio dos Pobres, criado na década de 1850, opunha-se ao Tre- 
ze de $M$ aio, abrindo espaço em suas páginas para as críticas ao governo provincial sob a égide conservadora. Assim sendo, o Piloto do Barquinho, personagem forjada pelos redatores do Correio dos Pobres, em suas críticas aos partidários da situação permite-nos perceber os embates travados na imprensa paraense: " $O$ Vô-vô Treze de $M$ aio de sabbado p.p. de bochechas inchadas como os odores de U lisses diz, que os clamores levantados pela imprensa local, há mezes a esta parte, sobre mocambos, escravos fugidosefome, são injustos, imprudentes emenos verdadeiros" (0 Correio dos Pobres, 27/08/1851, p. 04).

Disputas políticas na imprensa à parte, acerca dos mocambos e do grande número de escravos fugidos na província paraense, o próprio governo reconhecia a extensão do problema quer em suas falas e relatórios oficiais, quer em sua documentação policial reservada com as diversas autoridades. $\mathrm{N}$ a verdade, era difícil o estabelecimento de políticas de controle social e repressão dos movimentos dos trabalhadores escravos e dos de mais grupos das classes subalternas no período de 1840 a 1860, não somente pela falta de recursos financeiros e humanos necessários às forças policiais e militares, mas porque os embates havidos entre as facções e grupos políticos locaisfavoreciam as lutas escravas. Em 15 de agosto de 1854, Sebastião do Rêgo Barros, presidente da província, na abertura da Assembléia Legislativa Provincial, relatava:

Boatos assustadores espalharão-se em dias de abril do corrente anno, no districto de M onsarás, que alguns indivíduos turbulentos, alliciando escravos, pretendiam em a noite de sabado d'alleluia tentar contra a vida de vários cidadãos ali residentes. Logo quetive participação das respectivas autoridades fiz partir para lá uma força do 11ํㅡ Batal hão d'Infantaria de Linha, que voltou pouco dias depois por se não houverem felizmente verificado aquelles receios, eacharem-se de todos desvanecidos pelas averiguações feitas a tal respeito. ${ }^{15}$

É importante lembrar que as críticas e reclames senhoriais contra a ineficácia das autoridades públicas no combate às fugas e aos mocambos vislumbram a complexidade do universo social no qual encontravam-se inseridos escravos e pobres livres, muitos dos quais guardas da polícia, capitães-do-mato e soldadesca dos comandos militares da região, ou seja, 
agentes da repressão responsáveis imediatos pela aplicabilidade da legislação de controle social das classes subalternas. $\mathrm{N}$ a verdade, como as fronteiras sociais entre os mesmos constituíam-se imprecisas havia até mesmo 0 alistamento militar de escravos fugidos, sob o título de forro. Rufino, por exemplo, "fugiu da fazenda Valdecães durante muitos anos, servindo como praça em uma embarcação de guerra, e tem sinais de castigo que então sofrera" (0 Planeta, 27/09/1849, p. 03). Já em quatro de março de 1851, o presidente da província comunicava ao chefe de polícia que havia mandado "anular a praça do preto J oséD aniel, que....havia[sido] remetido como liberto com ofício de 26 do mês passado não só por o haver reclamado M aria Gertrudes de Amorim como seu escravo, como fez certo por documento que apresentou, mas pela própria confissão do mesmo preto quando foi inquirido pelo comandante do 40 Batalhão de Caçadores". ${ }^{16}$

A expressividade demográfica da população não-branca, particularmentenas classes subalternas, sobreas quais recaía o peso do recrutamento militar forçado, favorecia a diluição das diferenças raciais existentes entre pessoas livres e cativas, impondo dificuldades ao reconhecimento imediato de uns e outros por parte das autoridades militares e policiais. Em maio de 1853, por exemplo, certo anunciante reclamava a captura do cafuz claro Cicilio, "reputado até então por pessôa livre, he hoje requisitado como escravo" (0 Velho Brado do Amazonas, 28/05/1853, p. 06). Como Cicilio havia ou tros escravos que desapareciam no universo interétnico da população paraense, fazendo com que os critérios raciais de organização social vigentes na escravidão, embora usuais, não fossem determinantes da condição escrava. N este sentido, alguns escravos em fuga buscavam asilo no seio das próprias forças de repressão, assentando praça, embora existissem outros que mesmo não recrutados faziam uso do imaginário social que identificava a soldadesca com setores não-brancos da sociedade. Francisco, por exemplo, sempre que fugia costumava "dizer que foi soldado eque déo baixa", despistando as desconfianças sobre si (Treze de M aio, 04/02/ 1846, p. 04). O s próprios senhores partilhavam das mesmas representações sociais, calcadas em paradigmas raciais, acerca das imagens estereotipadasqueenvolviam recrutase praças: o tenentecoronel Anselmo Joaquim da Silva anunciava a fugida do preto retinto T homaz que, segundo o senhor, 
possuía "um buço tão serrado, que a primeira vista parece soldado pelo bigode" (Treze de M aio, 22/01/1845, p. 03-04); J oão Eduardo Rodrigues dos Santos também requeria a captura do molato $M$ anoel, pedreiro que fugira com "toda ferramenta de seu ofício", descrevendo que costumava "ter o cabello do bigodecrescidos, o que o poderá fazer passar por dezertor de primeira linha" (0 Planeta, 03/02/1852, p. 04).

Buços e bigodes típicos de caserna à parte, os próprios mocambos agregavam escravos negros, índios ehomens livres criminosos, réus da justiça, ou desertores das tropas policiais e militares. 0 utras vezes os escravos refugiavam-se nas aldeias indígenas, tecendo laços de solidariedade e relações familiares: em 1854, o Treze de M ai o noticiava o batizado de sete escravos do sr. Pedro Lourenço da Costa, informando serem todos "filhos de uma preta, escrava do mesmo senhor, a qual havendo fugido em 1835, teve aquêles filhos durante o tempo que estêve em fuga". Ainda sobre a escrava dizia o jornal quea mesma haviasido "agarrada em C amutá [C ametá], onde se inculcava livre, e confessa[va] ter vivido quase sempre entre os gentios Anhambés, habitantes da selva do Tocantins, em companhia de um prêto, criminoso, evadido da cadeia pública desta capital naquele ano de dolorosa rendição[1835]" (Treze de M aio, 10/01/1854, p. 08).

$\mathrm{N}$ a verdade, os escravos, os libertos e os pobres livres vivenciavam e compartilhavam suas diversas experiências sob a escravidão, forjando espaços de cumplicidade e conflitos. Assim sendo, não sofriam apenas os desmazelos da pobreza e o peso da opressão de uma sociedade autoritária baseada em relações sociais hierarquizadas, na qual a desigual dadee a diferença constituíam a norma. Tais personagens, interagindo formas e estratégias de lutas, não só formavam mocambos, como faziam com que as fugas nem sempre fossem somente fugas de escravos: a cafuza amolatada Raimunda, em fevereiro de 1850, "fugiu em companhia de uns desertores do Batalhão Provincial" rumo à região de Turiaçu e Bragança, área de quilombos (0 Publicador Paraense, 20/12/1850, p. 04); Roza, atapuiada, em janeiro de 1849 fugira, fazendo crer a sua senhora que estava "na ilha das 0 nças com um cafuz dezertor de bordo de nome Venâncio" ( 0 D outrinário, 25/07/1849, p. 04); Raimundo, ao fugir, "levou em sua companhia hum moço branco por nomej oséde 17 a 18 annos, magro, espigado, 
cara esguia, feiçoens finas, com hum pequeno signal ao comprimento do naris" (Treze de M aio, 28/06/1845, p. 03); G eraldo, fugiu em dezembro de 1847, "tendo levado em sua companhia, duas tapuias e dous curumins que estavão em casa do annunciante" (0 D outrinário, 16/08/1848, p. 02); Jozé havia fugido "em companhia de um italiano, que fazia dançar um macaco, dizendo ser livre" (0 Planeta, 07/03/1850, p. 04).

Para uns e outros, entretanto, não faltavam as devidas políticas de controle social. Aos escravos cabia o exercício cotidiano do domínio dos senhores, auxiliado pelo cipó de rêgo. Aos libertos e pobres livres, geralmente mestiços, estava reservado o recrutamento militar forçado, quando não ficavam engajados sob o regimedo Corpo deTrabalhadores. N estesentido, Jerônimo Francisco Coelho, presidente da província, em 27 de julho de 1848, determinava como regra invariável o seguintetratamento dispensado aos homens pobres livres e forros:

$1^{\circ}$ - Todo equalquer indivíduo livreou liberto, quefor prezo policialmente, e tiver de ser solto pela polícia, será mandado [se] apresentar ao quartel do Comando das Armas, com uma explicativa contendo nome, naturalidadee idade, estado e profissão ou offício, elugar sabido de sua residência, motivo da prisão e observação sobre o juízo que de sua moralidade faz a polícia a fim de serem mandados para o serviço do exército [ou] armada, os que não tiverem isenção legal ao seu favor. ${ }^{17}$

Q uanto aosescravos, o presi denteda província detalhava as razõespelas quais eles deviam ser presos e castigados pela força policial sendo entregues aos seus senhores somente após o necessário corretivo disciplinador, exigindo maior rigor na vigilância cotidiana dos movimentos dos trabaIhadores cativos, coibindo-Ihes quaisquer espaços e formas de contestação ao domínio senhorial:

$2^{\circ}-$ Todo e qualquer escravo prezo pela polícia por desordem, desobediência ou falta de respeito ou por ser encontrado depois do toque de recolher sem bilhete de seu senhor, não será sol to sem sofrer castigo de cincoenta até duzentos açoites, conforme a gravidade da falta. ${ }^{18}$

Enquanto os escravos acabavam devolvidos aos senhores, os indivíduos livres e libertos presos policialmente eram submetidos ao processo 
de recrutamento militar forçado, sendo transformados paradoxalmenteem soldados responsáveis diretos pela manutenção da ordem social junto às próprias classes subalternas. 0 u seja, através da submissão à autoridade militar e policial procurava-se disciplinar e corrigir nos quartéis os marginais e as pessoas perigosas ao sossego público, incorporando-os ao serviço da própria ordem social estabelecida. Por exemplo, em 31 dejaneiro de 1848, H erculano Ferreira Pena, presidente da província, comunicava ao chefe de polícia que havia mandado colocar à "sua disposição o preto C laudio Antônio D'O liveira, que diz ser forro efilho da Bahia, remetido prezo pelo comandante militar de porto de M óz por ter aparecido ali sem passaporte"; na verdade, Claudio Antônio, sob a desconfiança de que fosse "escravo ou marinheiro", foi recrutado "por estar, quando não seja escravo, nas circunstâncias de assentar praça", justamente porque havia sido classificado como muito "turbulento e mal intensionado". ${ }^{19}$

D esta forma, não seria nada estranho perceber certas facetas da convivência dos agentes da lei com outros segmentos sociais das classes subalternas, como revela a seguinte notícia estampada no D iário do Commércio:

À ordem do D r. ChefedePolícia forão presoso soldado do 11 을 Batal hão de Infantaria de Linha Julião Fernandes, e o preto escravo João Vicente por embriaguez e desordem (D iário do Commércio, 07/05/1859, p. 02).

Vê-se, portanto, que certos sujeitos, mesmo assentando praça, não se compenetravam de seus sagrados deveres de botar freios nas ações indisciplinadas dos escravos, pelo contrário, continuavam persistindo na mesma vida de turbulências e más intenções ao lado de camaradas escravos, libertos ou livres. Até mesmo os capitães-do-mato, famosos por suas perseguições aos negros fujões, encontravam-se partilhando com os cativos os espaços sociais marcados pela cumplicidade e conflitos. Inclusive, porque a convivência não desinteressada com os cativos podia render aos capitães-do-mato determinadas informações relativas àquele ou outro escravo fugitivo, bem como o mapeamento das relações sociais existentes entre os cativos eos demais setores livres da população. N este sentido, na década de 1850 eram publicadas na imprensa não somente diversas queixas contra algazarras feitas pela reunião dos escravos nas tabernas, praças, ruas e 
cantos da cidade de Belém, recriminando-se o desleixamento dos guardas policiais, como denúncias acerca do comportamento dos capitães-do-mato:

Cumpre pois que as nossas autoridades policiais tomem em consideração 0 que vimos de expor, e esperamos igualmente que as mesmas autoridades se recordem do que mais uma vez tem dito a imprensa relativamente aos capitães-do-mato; pois essa gente são os próprios que pactuam com os escravos; e nessas reuniões pelas ruas sempre se observa que entre êles acha-se um capitão-do-mato pelo menos; eno entretanto que êsses verdadei ros esbirros do inferno, flagelam os taberneiros e a que[m] se conserva pacífico até em sua própria casa. Se pois houvesse que[m] nos livrasse de semelhante praga chamada de capitão-do-mato, policiando a cidade, fazia decerto um grande serviço aos habitantes desta capital (0 Planeta, 27/11/1851, p. 01).

É importante frisar, entretanto, que os espaços sociais de convivência entre escravos, libertos e pobres livres cadenciavam-se por relações complexas de camaradagem e conflito, nos quais forjavam-se alianças e inimizades, pactuavam-se parcerias e ocorriam rupturas. D esta forma, o intercâmbio de experiências e estratégias de lutas entre uns e outros também conheciam limites impostos pelas frontei ras de cada condição social específica, embora as mesmas estivessem muitas vezes entrelaçadas no cotidiano da escravidão. 0 u seja, determinados val ores e visões de mundo próprios aos sujeitos submetidos como escravos ao domínio senhorial faziam parte de uma cultura escrava; enquanto pessoas pobres livres possuíam outras percepções e leituras da própria escravidão, a partir do exercício cotidiano da liberdade negada aos cativos. Assim sendo, não era incomum a mesma polícia que sofria críticas por viver no meio da súscia de escravos, em determinados momentos usar do cipó de rêgo a fartar na repressão e policiamento dos trabalhadores cativos, como relatava o seguinte anúncio defuga:

Anda vagando pelos subúrbios desta cidade, um prêto, escravo, oficial de pedreiro, denomeG regório, ainda rapaz, um tanto cambaio, bem conhecido pela polícia, por ter sido há pouco tempo, castigado nas grades da cadeia por insultar um camarada da mesma polícia... (TrezedeM aio, 19/12/1854, s/p.).

Enquanto Gregório recebia chibatadasna cadeia, o escravo Raimundo escapava em Carnapijó dos “soldados da polícia que alli forão em diligên- 
cia" em busca desua pessoa (TrezedeM aio, 21/05/1845, p. 06). N estesentido, tais escravos, entre tantos outros, sabiam perfeitamente que, camaradagens à parte, os agentes da repressão e os cativos ocupavam papéis diferenciadose contrários nos mundos da escravidão. M as, os conflitos sociais também estavam presentes nas próprias rel ações entre os escravos no cotidiano da suas labutas diárias, em suas disputas pelo mercado de trabal ho e pelas relações amorosas ou simplesmente porque resolviam dar vazão a velhas rixas há muito tempo guardadas. Em janeiro de 1859, por exemplo, por ordem do chefe de polícia havia sido preso "o preto escravo José, por querer ferir a outro com umafaca” (D iário do Commércio, 10/01/1859, p. 02).

Por outro lado, a energia com que as principais autoridades governamentais impunham à necessidade de maior severidade na aplicação da legislação de controle social e no exercício das práticas repressivas de manutenção da ordem pública, reconhecendo muitas vezes a própria inoperância da máquina administrativa em suas funções policiais de vigilância sobreos movimentos das classes trabalhadoras, particularmente os escravos, indica-nos mais uma vez que nem sempre os agentes da repressão personificados pelos guardas e soldadesca cumpriam fielmente com suas obrigações, conforme as ordens superiores, embora não fossem impedidos de cumprilas. Sobre a questão, ponderava 0 Velho B rado do Amazonas, no artigo Ainda os Q uilombos, publicado em 17 de junho de 1851:

...; abalançamo-nos mesmo a assegurar que o exm. snr. prezidente, e o illm. snr. chefe de polícia da província não continuarão a sancionar 0 indifferentismo com quetem sido tratadososquilombosquepovoão asmatas não só remotas, mas até visinhas da capital. As queixas fervem de todos os pontos; a fuga de escravos continua em grande escalla; os quilombos tem emissários nas cidades; os escravos tranzitão com maior a liberdade as deshoras pel as ruas da própria capital. Sem bilhete de guia de seus senhores, frequentão batuquesnoturnos, possuem casas al lugadas por sua conta, eisto em contraven ção de leys em vigor; entretanto a policia nada disto tem vedado! 0 s mesmos escravos aquilombados visitão de noite a capital; e portão ao porto do Sal, venden do lenha, carvão, fructas, ecomprão do que precizão; há mesmo ahí taberneiro tão vil que se correspondecom elles; que os fornece de comestiveis, e até polvora e armas; tudo isto o povo sabe; ea policia? Tudo tem ignorado! ou a tudo tem fechado os olhos! 
Cremos porém que teremos remédios, porque os clamores da vários lavradores e proprietáriosjá tem chegado à ouvidos da prezidencia, eda chefatura de polícia.

Assim sendo, épossível compreender como inspetores dequarteirões, capitães-do-mato, policiais e soldados compartilhavam determinados espaços sociais dentro da sociedade escravocrata, no qual escravos, libertose outros setores da população livre teciam, desmanchavam e refaziam as suas teias de relações sociais, tais como os taberneiros da cidade de Belém que negociavam com os mocambeiros que furtivamente visitavam a capital paraense na cal ada da noite, adquirindo al imentos, munições e armas de fogo. O s mesmos mocambeiros que enviavam seus emissários à cidade, trocando informações com outros escravos urbanos ou com aquel es que se encontravam em fuga. Enfim, os mesmos mocambeiros que durante a década de 1850 sofreram forte repressão por parte do governo provincial, em suas expedições dirigidas contra os quilombos situados nas proximidades de Belém, como, por exemplo, M ocajuba que embora não destruído totalmente acabou bastante enfraquecido deixando de "preocupar as atenções do governo"(SALLES, 1988:230).

\section{Considerações finais}

$\mathrm{N}$ este artigo foi esboçado o contexto histórico da província paraense durante o período de 1840-1860, a partir especificamente do movimento de fugas de escravos. D este modo, foi necessário fazermos referências às décadas anteriores a 1840, marcadas pela agitações sociais e políticas relativas ao processo de independência e formação do império, destacando-se osanos consumidos pela C abanagem (1835-1840), cujas feridas ainda não haviam cicatrizados na sociedade paraense, tanto que a $\mathrm{C}$ abanagem durante as décadas seguintes ainda era uma dolorosa recordação, justamente porque as classes subalternas, entre as quais os cativos, haviam lutado contra os segmentos das classes proprietárias, os chamados homens de bem. $\mathrm{Na}$ verdade, o próprio movimento de fugas de escravos durante 1840-1860, bem como a reação senhorial, só podem ser entendidos dentro do processo de reorganização da sociedade paraense no pós-C abanagem. 0 u seja, 
enquanto os escravos procuravam manter sua luta pela liberdade, mesmo isolados, através das fugas em grande quantidade; os senhores procuravam coibir os seus cativos auxiliados pelas autoridades provinciais.

N este contexto, os escravos fugiam em direção aos diversos mocambos espal hados pela província paraense; bem como evadiam-seem direção ao outro lado da fronteira, particularmente à G uiana Francesa, realizando neste último caso fugas para fora. ${ }^{20}$ Também fugiam dissimulando a sua condi ção escrava entre os setores livres da população não-branca da região. Por sua vez, a tamanha quantidade das fugas de escravos aumentava os receios das classes proprietárias de uma nova revolução, fazendo com que os senhores atormentados pelos fantasmas da C abanagem viessem em suas queixas a aumentar a dosagem do perigo da ousadia einsubordinação dos escravos. $N$ as décadas de 1840 e 1850 os senhores também acompanhavam temerosos a rebeldia escrava, particularmente as fugas, em razão das notícias sobre possíveis insurreições escravas em outras partes do I mpério e das Américas, ao mesmo tempo em que as pressões britânicas contra 0 tráfico negreiro, extinto em 1850, deixavam inquietos os trabalhadores cativos e seus senhores. Em suas leituras políticas daquel e período os escravos forjavam as suas formas de protesto e de luta contra o domínio senhorial, endossan do o movimento defugas na província do Grão-Pará, demonstrando-nos queterminada a $\mathrm{C}$ abanagem as lutas sociais não haviam necessariamenteencerrado. No caso dos trabal hadores escravos, portanto, as suas experiências vivenciadas durante a Cabanagem, chamada pelos senhores detempo da malvadeza, não foram esquecidas, pelo contrário formatavam o movimento de fugas realizados pelos mesmos nas décadas seguintes.

Por outro lado, o período de 1840 a 1860 fora marcado pelo processo de construção da hegemonia saquarema, sob a líderança dos diversos segmentos conservadores da sociedade, em razão das derrotas sofridas pelos grupos políticos liberais em diversas regiões do império brasileiro. ${ }^{21}$ Assim sendo, a consolidação do Império sob a hegemonia saquarema significava o próprio fortalecimento das formas de controle social das classes trabaIhadoras, particularmente sobre os cativos, dificultan do a ocorrência denovas rebeliões escravas na época pós-1860. Entretanto, no período de 18601888 os escravos continuaram fugindo em busca da liberdade, fazendo do 


\section{abolicionismo espaço de novas lutas e de outras histórias (BEZERRA NETO , 1993).}

\section{Notas}

${ }^{1}$ Sobre a primeira metade do século XIX no Pará, há al guns estudos que fazem registros da participação dos escravos nas lutas políticas da época. Ver por exemplo: SALLES (1988 [1971]); RAIO L (1970); M UNIZ (1922); BARATA, (1975); ACEVEDO M ARIN (1992). N estes estudos, enquanto o primeiro e o último dão ênfase à participação dos escravos durante as lutas pela independência, considerando-os agentes políticos de suas próprias histórias, os demais autores assemel ham-se em situar a participação dos escravos à reboque das lutas político-partidárias entre as elites, destituindo os cativos de quaisquer fórum de decisão própria.

${ }^{2}$ Sobre o assunto, ver o trabal ho deREIS (1989). Embora esteautor dedique-se ao estudo do caso baiano, é possível pensar assemelhadamente, guardada as devidas diferenças, em relação ao Grão-Pará.

${ }^{3} \mathrm{~A}$ C abanagem ocorreu na província paraense durante o período regencial, iniciando-se em 7 de janeiro de 1835 com a tomada de Belém, capital do Grão-Pará, pelos cabanos, assim denominados em função deque o grosso de seus participantes eram sujeitos pobres que habitavam em cabanas nas margens dos rios da região amazônica, embora pessoas de condição social e econômica remediada e mais abastada também tivessem tomado parte deste movimento rebelde. $\mathrm{D}$ esta forma, tomaram parte da $\mathrm{C}$ abanagem homens livres pobres, ao lado de escravos e índios, bem como senhores de escravos e proprietários agrícolas, além de sitiantes e posseiros. A pós a tomada de Belém, os cabanos efetivamente conquistaram o poder na província, conhecendo três breves e sucessivos governos. 0 fim do terceiro governo cabano, presidido Eduardo Angelim, ocorreu quando os rebeldes abandonaram definitivamente a cidade de Belém, em 13 de maio de 1836, logo ocupada pelas tropas do governo regencial comandadas pelo brigadeiro Andrea, mas a C abanagem ainda continuaria por al guns anos, até1840, quando o último grupo de rebeldes rendeuse em Luzéa, no atual estado do Amazonas.

${ }^{4}$ Segurança Pública: Chefatura dePolícia da Província, Livro de Registro deO fícios, Livro 07: Abril a junho de 1848, Arquivo do Estado do Pará - APEP.

${ }^{5}$ Sobre aquestão, ver SALLES (1988); ACEVED O M ARIN (1992); eG O M ES (1997). Ainda, sobre a circulação das idéias francesas entre os escravos paraenses e sua associação com 0 abolicionismo, durante a segunda década do XIX, ver por exemplo o papel desempenhado pelo Frei Luís Zagalo junto a escravaria. Estefranciscano do Convento de N ossa Senhora de Jesus, recém-chegado de Lisboa em 1815, dois anos depois era expulso deBelém edo Grão-Pará devido suas pregações políticas do direito dos escravosà liberdade. Segundo Baena, na mesma época em que Frei Zagal o fazia suas pregações do púl pitos, havia denúncias de que os negros da vila deV igia planejavam rebelar-see invadir a capital paraense, colocando em estado dealerta as tropas regulares (cf. BAEN A, 1969:293). Arthur 
Cézar Ferreira Reis, por sua vez, dizque as palavras do Frei Zagalo fomentaram as agitações dos escravos, particularmente em Cametá, onde uma "tentativa de pronunciamento dos negros" provocara intranqüilidade muito grande entre os moradores (cf. REIS apud SALLES, 1988:242).

${ }^{6}$ Segurança Pública: Chefatura dePolícia da Província, Livro de Registro de O fícios, Livro 07: Abril a junho de 1848, APEP (grifos meus).

${ }^{7} \mathrm{D}$ urantea primeira metade do século XIX, segundo G enovesehouveo "momento crítico", caracterizado na Afro-A mérica pela sempre presente ameaça da revolução negra. Sobrea questão, ver GEN OVESE (1983).

${ }^{8}$ Segurança Pública: Chefatura de Polícia da Província, Livro de 0 fícios do Presidenteda Província, vol. 10, 23 de maio de 1854, APEP.

${ }^{9}$ Ver LINEBAU GH (1983). Ver, ainda, o debate SWEEN Y (1988) e LIN EBAU GH (1988).

${ }^{10} \mathrm{Em} 11^{\circ}$ de dezembro de 1900,sob arbitragem do governo suíço, fora definitivamente estabelecido os limites da fronteira entrea $G$ uiana Francesa e o Brasil, com ganho de causa favorável aos brasileiros. D esta forma, a zona do contestado declarada neutra em 1841 ficava sob jurisdição da república brasileira, representando uma área de 260.000 quilômetros quadrados.

${ }^{11}$ Ver: Falla que o Excmo Sr. Conselheiro Sebastião do Rêgo Barros, presidente desta província, dirigiu à Assembléia Legislativa Provincial, na abertura da mesma Assembléia no dia 15 de agosto de 1854, p. 39.

${ }^{12}$ Ver: Falla dirigida à Assembléia Legisl ativa da Província do Pará, na segunda sessão da XI legislatura pelo tenentecoronel $M$ anoel de Frias e Vasconcellos, presidenteda mesma província, em 10 de outubro de 1859, p. 64.

${ }^{13}$ Ver: Falla dirigida pelo Presidente da Província do G rão-Pará, H erculano Ferreira Pena, à Assembléia Legislativa Provincial, na abertura da sessão extraordináriano dia 08 demarço de 1847.

${ }^{14}$ Ver: Relatório do Presidente da Província do Grão-Pará, D r. João da Silva G arrão, apresentado à Assembléia Legislativa Provincial, em 07 de abril de 1858, apud SALLES (1988: 216).

${ }^{15}$ Falla que o Excm으. Conselheiro Sebastião do Rego Barros, Presidente desta Província, dirigiu à Assembléia Legislativa Provincial, na abertura da mesma Assembléia no dia 15 de agosto de 1854, p. 03 (grifo nosso).

${ }^{16}$ Segurança Pública: Secretaria de Polícia da Província, Livro de 0 fícios do Presidentea Chefe de Polícia, vol. 08, período de 02 de janeiro a 30 de dezembro de 1850. APEP.

${ }^{17}$ Segurança Pública: Chefatura dePolícia daProvíncia, Livro de Registro de 0 fícios, Livro o 07, período: abril a junho de 1848.

${ }^{18}$ Segurança Pública: Chefatura dePolícia da Província, Livro de Registro de 0 fícios, Livro no 07, período: abril a junho de 1848 . 
${ }^{19}$ Segurança Pública: Chefatura dePolícia da Província, Livro de Registro de O fícios, Livro oㅡ 07, período: abril a junho de 1848.

${ }^{20}$ Sobre o conceito de "fugas para fora", ver SI LVA (1989:62-78). Entretanto, tomando por empréstimo o uso do termo "fugas parafora" não levamos junto a sua definição proposta por Eduardo Silva, preferindo dotar o referido termo de outra significação e aplicação no estudo das fugas de escravos na Amazônia, enquanto literalmente fugas para fora da sociedade escravocrata brasileira rumo as regiões fronteiriças do Império, cruzando as mesmas. N estesentido, qual quer outra tradição de fuga escrava não poderia, ao nosso ver, ser considerada como "para fora".

${ }^{21}$ Sobre o processo de construção da hegemonia saquarema, ver M AT TO S (1990).

\section{Referências Bibliográficas}

ACEVED O M ARIN, Rosa Elizabeth. "A influência da Revolução Francesa no G rão-Pará". In: CU N H A, JoséC arlosC . da (org.). Ecologia, desenvolvimento e cooperação na Amazônia. Belém, U N AM AZ/U FPa, 1992, pp. 34-59.

BAEN A, Antônio Ladislau M onteiro. Compêndio das Eras da Província do Pará. Belém,U FPA, 1969.

BARATA, M anoel. Poder e Independência no Grão-Pará (1820-1823). G ênese, estrutura efatos deum conflito político. Belém: C onselho Estadual de Cultura, 1975.

BEZERRA N ETO , José M aia. "A vida não é só trabalho: fugas escravas na época do abolicionismo na Província do Grão-Pará (1860-1888)". In: Cadernos do Centro deFilosofia e Ciências H umanas da U FPa, vol. 12, n. 1/2, 1993, pp. 141-154.

CARD OSO, Ciro Flamarion S. E conomia e sociedade em áreas coloniais periféricas: Guiana Francesa ePará, 1750-1817. Rio de Janeiro, Graal, 1984.

FUNES, Eurípides. 'N asci nas matas: nunca tive senhor': história e memória dos mocambos do Baixo Amazonas. Tese de doutorado, São Paulo: USP, 1995.

GEN O VESE, Eugene. D a Rebelião eRevolução. São Paulo, G lobal Editora, 1983. GOM ES, Flávio dos Santos. A H ydra e os Pântanos: Q uilombos e M ocambos no Brasil - Sécs. XVII a XIX. Tese de doutorado, Campinas, U nicamp, 1997. H URLEY, H enrique Jorge. TraçosC abanos. Belém: Instituto L auro Sodré, 1936. LIN EBAU G H , Peter. "Todas as montanhas atlânticas estremeceram". In: Revista Brasileira de H istória, no 06, São Paulo: AN PU H /M arco Zero, setembro de 1983. 
LIN EBAU GH , Peter. "Réplica”. In: Revista Brasileira de H istória, vol. 08, o 16, São Paulo: AN PU H /M arco Zero, mar/1988 - ago/1988, pp. 221-230.

M AT TO S, IImar Rohloff de. 0 tempo Saquarema. A formação do estado imperial. São Paulo: H ucitec, 1990.

M U N IZ, João Palma. "Adhesão do G rão Pará à Independência". In: Revista do Instituto H istórico e G eográfico do Pará, ano 6, no 09, Belém: IH G P, 1922.

RAIO L, D omingos Antônio. M otins Políticos, ou história dos princi pais acontecimentos políticos da Província do Pará desde 0 ano de 1821 até 1835 . Belém, UFPa, 1970, 03 volumes.

REIS, Arthur C ézar Ferreira. A Amazônia ea cobiça internacional. Rio deJaneiro, Civilização Brasileira; M anaus, Superintendência da Zona de Franca de M anaus, 1982.

REIS, João José. "O jogo duro do D ois de Julho: o 'Partido N egro' na Independência da Bahia". In: REIS, João J osé e SI LVA, Eduardo. N egociação e conflito. A resistência negra no Brasil escravista. São Paulo: Companhia das Le tras, 1989.

SALLES, Vicente. 0 N egro no Pará. Sob o regimeda escravidão. Braślia: M inisté rio da Cultura; Belém: Secretaria de Estado da Cultura; Fundação Cultural do Pará "Tancredo N eves", 1998 [1971].

SI LVA, Eduardo. "Fugas, revoltas equilombos: os limites danegociação". In: REIS, João J osé\& SILVA, Eduardo. Negociaçãoe conflito. A resisência negra no Brasil escravista. São Paulo, Companhia das Letras, 1989, pp. 62-78

SWEEN Y, Robert. "O utras can ções de liberdade: U ma crítica de 'Todas as montanhas atlânticas estremeceram' ". In: Revista Brasileira de H istória, vol. 08, no 16, São Paulo: AN PU H /M arco Zero, mar/1988 - ago/1988, pp. 205219.

VIAN N A, Arthur. "N otícia H istórica”. In: PARÁ, Governo do. 0 Pará em 1900. Belém: Imprensa de Alfredo Augusto Silva, 1900.

\section{Resumo}

Neste trabal ho apresentamos e discutimos al guns aspectos dos "movimentos" de fugas de escravos ocorridos na Província do Grão-Pará, durante basicamente a primeira metade do século XIX, observando-se as suas principais características, tais como: as fugas em grupos e a sua expressividade; as fugas para fora do Império do Brasil; as 


\section{2 - TOPOI}

fugas para os mocambos; constituindo-se as fugas estratégi as de lutas não somente escravas, mas compartil hadas por outros segmentos das classes subal ternas. N este sentido, procuramos perceber o contexto histórico que dotava as fugas de escravos neste momento de determinadasespecificidades, diferenciando-asdeoutrasépocas, taiscomo as últimas décadas do século XIX.

\section{Abstract}

ThisWork analyses the variousaspects of slaves runaways movementsin Província do Grão-Pará, during the first half of the nineteenth century, looking to its principal caracteristics, as: the runaways in groups and its significant; the runaways out of the B razil'sEmpire, the runaway to the mocambos, not being these runaways estrategy of struggleslaves only, but shared with others segments of thesubaltern dasses. Theauthor seeks to discern how the historical context in thismoment determinated the meanings of the runaways, making them different from the ohters times, as the last decades of the nineteenth century. 